\title{
Skeletal growth, morphology and skeletal parameters of a temperate, solitary and zooxanthellate coral along a depth gradient in the Dardanelles (Turkey)
}

\author{
H. B. Özalp ${ }^{1}$ E. Caroselli ${ }^{2}$ (D) F. Raimondi ${ }^{2}$ S. Goffredo ${ }^{2}$
}

Received: 6 October 2017/ Accepted: 10 April 2018/Published online: 19 April 2018

(C) Springer-Verlag GmbH Germany, part of Springer Nature 2018

\begin{abstract}
Studying coral populations along depth gradients is important to find out if deeper habitats can act as microrefugia from bleaching and/or mortality events associated with high temperature and irradiance. Skeletal biometry, growth, and parameters of the solitary, zooxanthellate, Mediterranean endemic scleractinian Balanophyllia europaea were determined at depths of 1,11 , and $21 \mathrm{~m}$ in the Dardanelles (Turkey), to (1) compare the population parameters in the Eastern Mediterranean Sea with the wellcharacterized populations in the NW Mediterranean Sea, that are threatened by ocean warming and acidification; and (2) assess the variation of studied parameters along a depth gradient in the Dardanelles. Biometric relationships were similar to those previously described on Italian coasts. At shallow depths, average coral height decreased, likely because of (1) the higher current velocity and wave action that is expected to limit vertical skeletal growth and/or (2)
\end{abstract}

Topic Editor Morgan S. Pratchett

H. B. Özalp and E. Caroselli have contributed equally.

Electronic supplementary material The online version of this article (https://doi.org/10.1007/s00338-018-1687-9) contains supplementary material, which is available to authorized users.

\footnotetext{
H. B. Özalp

barisozalp@comu.edu.tr

$\triangle$ E. Caroselli

erik.caroselli@unibo.it

1 Vocational School of Ocean Engineering, Section of Underwater Technology, Çanakkale Onsekiz Mart University, Terzioglu Campus, 17020 Canakkale, Turkey

2 Marine Science Group, Department of Biological, Geological and Environmental Sciences, University of Bologna, Via F. Selmi 3, 40126 Bologna, Italy
}

the need to increase photoprotection in high light conditions. Only a very slight increase of skeletal bulk density with depth (and consequent slight decrease of porosity) was detected, while age-length relationship, linear extension rate and net calcification rate were homogeneous among depths. The homogeneous net calcification rate with depth may depend on the balance between the response of zooxanthellae photosynthesis to temperature and light. In fact, shallow depths are likely to experience higher temperatures that negatively affect photosynthetic efficiency of B. europaea, thus reducing available energy for calcification. On the other hand, lower light availability with depth is expected to decrease photosynthesis and these two effects may compensate each other. Unexpectedly, the observed net calcification rate in the Dardanelles was almost double than the higher value reported in the northwestern Mediterranean Sea. Further analyses are required to analyse if energetic trade-offs between skeletal growth and reproduction differ in the two regions.

Keywords Balanophyllia europaea - Dendrophylliidae · Turkish Straits System - Calcification - Skeletal density . Porosity

\section{Introduction}

Physiological processes of organisms (e.g., calcification, photosynthesis and respiration), including corals, strongly depend on environmental conditions (Edmunds and Gates 2002; Reynaud et al. 2003; Krief et al. 2010). The growth and morphology of many corals are affected by environmental factors such as light, water flow, gravity (Todd 2008, and references therein), pH (Fantazzini et al. 2015), temperature (Goffredo et al. 2007, 2009; Kružić et al. 
2012), and proximity of other specimens (Elahi 2008). Even depth influences coral growth and morphology of some scleractinians. Light irradiance declines with depth and ambient temperature is often lower in deeper waters, which may act as refugia from bleaching and/or mortality events associated with high temperature and irradiance (Kleypas et al. 2008; Bridge et al. 2014). Thus, information on deeper coral populations is useful to assess if they can provide a critical source of propagules to assist the recovery of adjacent shallow-water populations (Bridge et al. 2014). In Porites astreoides, Montastraea annularis, Colpophyllia natans and Siderastrea siderea in Jamaica, linear extension rate is less in deeper populations, likely as a response to reduced light and zooxanthellae photosynthesis (Huston 1985). In M. annularis from the Virgin Islands (USA), linear extension rate decreases at depths $>9 \mathrm{~m}$ due to lower light, while bulk skeletal density and net calcification rate (which are maximum at intermediate depths, 7.5-15 m) are higher due to colder temperatures (Baker and Weber 1975).

Coral skeletal growth comprises three related characters: net calcification rate, bulk skeletal density and linear extension rate (net calcification rate $=$ bulk skeletal density $\times$ linear extension rate; Lough and Barnes 2000; Carricart-Ganivet 2004), whose measurement is essential when assessing the environmental modulation of coral skeletal growth, because none of the three parameters is a perfect predictor of the other two (Dodge and Brass 1984). These three variables have been investigated along tropical latitudinal gradients in Porites (Grigg 1982; Lough and Barnes 2000) and Montastraea, in relation to temperature and light variation (Carricart-Ganivet 2004). Many studies on coral skeletal density have focused on bulk density, which is the mass divided by the total enclosed volume, including the volume of the enclosed skeletal voids (porosity). Another measure of skeletal density is microdensity (mass per unit volume of the material which composes the skeleton; Barnes and Devereux 1988). As porosity decreases, bulk density approaches micro-density, which cannot exceed the density of pure aragonite (2.94 $\mathrm{mg} \mathrm{mm}^{-3}$; Bucher et al. 1998), owing to the presence of an intra-crystalline organic matrix (Cuif et al. 1999). Bulk density, porosity and micro-density relate to architechtural features of the skeleton (Chamberlain 1978) but have rarely been investigated together (e.g., Bucher et al. 1998; Caroselli et al. 2011; Goffredo et al. 2015), even though they influence the ability of coral skeletons to resist natural (Rodgers et al. 2003) and anthropogenic breakage (Liddle and Kay 1987).

In species that rarely show fragmentation or fusion, it is possible to determine coral age (Chadwick-Furman et al. 2000), as reef-building corals and solitary scleractinians record annual growth bands in their skeleton (Pratchett et al. 2015, and references therein). Growth-band analysis has been largely used to determine the age of tropical colonial scleractinians (e.g., Knuston et al. 1972; Buddemeier and Maragos 1974; Logan and Anderson 1991) as well as in tropical (Goffredo and Chadwick-Furman 2003) and temperate solitary forms (e.g., Goffredo et al. 2008; Caroselli et al. 2012, 2016), allowing to obtain information of skeletal growth rate during the whole lifespan of the coral.

Balanophyllia europaea (Risso, 1826) is a solitary, zooxanthellate scleractinian that lives on rocky substratum and is endemic to the Mediterranean Sea (Zibrowius 1980). It is found at depths from 0 to $50 \mathrm{~m}$ (Zibrowius 1980). From a phylogenetic perspective, it shows a unique set of character traits within the family Dendrophylliidae (Arrigoni et al. 2014). Even though recent investigations of Turkish scleractinian fauna in the Dardanelles report $B$. europaea as one of the dominant shallow-water scleractinians, with peaks of around 400 individuals $\mathrm{m}^{-2}$ (Özalp and Alparslan 2016), no information is available on skeletal growth rate and parameters at this location. In the well-characterized populations of the northwestern Mediterranean Sea, the oral disc of B. europaea becomes more oval as it grows older (Goffredo et al. 2004, 2007) and skeletal growth decreases with age (Goffredo et al. 2008). High temperatures lead to a reduction in abundance (Goffredo et al. 2007), net calcification rate and bulk skeletal density of this species (Goffredo et al. 2009), due to a thermal inhibition of symbiont photosynthesis and consequent decrease of available energy for the coral (Caroselli et al. 2015a). Reduction in net calcification rate with increasing temperature leads to less dense and more porous skeletons (Caroselli et al. 2011), due to an increase of larger pores (Fantazzini et al. 2013). This determines a decrease in the stiffness of skeletons, which become less resistant to physical breakage (Goffredo et al. 2015). Seawater acidification reduces net calcification rate and bulk skeletal density of this species due to increased porosity, while linear extension is maintained to reach the size at sexual maturity (Fantazzini et al. 2015).

The aims of this study were to (1) compare for the first time the skeletal biometry, growth, and parameters of $B$. europaea populations in the Eastern Mediterranean Sea with the well-characterized populations in the NW Mediterranean Sea, which are threatened by ocean warming and acidification; and (2) assess the variation of studied parameters along a depth gradient in the Dardanelles, to obtain information on the different responses to environmental conditions that characterizes deeper and shallow populations. 


\section{Materials and methods}

\section{Sampling area}

Sampling was performed in the Guzelyali region of the Dardanelles, Turkey $\left(40^{\circ} 02^{\prime} 04^{\prime \prime} \mathrm{N} ; 26^{\circ} 20^{\prime} 02^{\prime \prime} \mathrm{E}\right.$; Fig. 1), the only area where abundant populations of $B$. europaea occur throughout the strait (Özalp et al. 2014). Although it is a continuous part of the central Marmara basin and mainly under effect of the flows from the Black Sea, the strait hosts a peculiar biodiversity with mixed Mediterranean and Black Sea species, with some unique habitats of seaweeds, corals, gorgonians, sponges and coralligenous assemblages of Mediterranean origin (Özalp and Alparslan 2016). The seafloor mainly consists of sand with sparse boulders and rocks.

\section{Sample collection}

From 1st January to 1st August 2015, 30 specimens of $B$. europaea (Fig. 2a) were haphazardly collected by scuba divers along each of three 20-m long horizontal transects (parallel to coastline) at 1,11 , and $21 \mathrm{~m}$ depth (90 specimens in total). Samples were transported to the marine science laboratory at Çanakkale Onsekiz Mart University (COMU) and deposited in the Piri Reis Naval Museum (Faculty of Marine Science and Technology) with the code number COMU/PRM-CR 2015/Be1-Be90.

\section{Sample analysis}

Tissue of collected corals was removed by immersion in a $10 \%$ commercial bleach solution for 3 days and then corals were dried in an oven at $50{ }^{\circ} \mathrm{C}$ for 4 days. A low drying temperature was used to prevent transitions in skeletal carbonate phases (Vongsavat et al. 2006) and allow further characterization of skeletal crystallography (Goffredo et al. 2012). Each sample was observed under a binocular microscope to remove fragments of substratum and calcareous deposits produced by other organisms. Skeletal length (L: maximum axis of the oral disc), width (W: minor axis of the oral disc) and height (h: oral-aboral axis) were measured using a caliper (Fig. 2b) and volume was calculated with the formula $V=\frac{L}{2} \times \frac{W}{2} \times h \times \pi$ (Goffredo et al. 2007). Corallite mass (M) was determined with an Ohaus Explorer Pro analytical balance $( \pm 0.0001 \mathrm{~g}$; Caroselli et al. 2011).

\section{Age determination and skeletal growth modeling}

The age of collected corals was determined based on the observation that temperate scleractinians deposit one highdensity band in winter and one low-density band in summer (Peirano et al. 1999). Age was determined by counting the growth bands on computerized tomography (CT) tangential scans performed through the whole skeleton, by selecting a slice cutting a whole septum and where growth

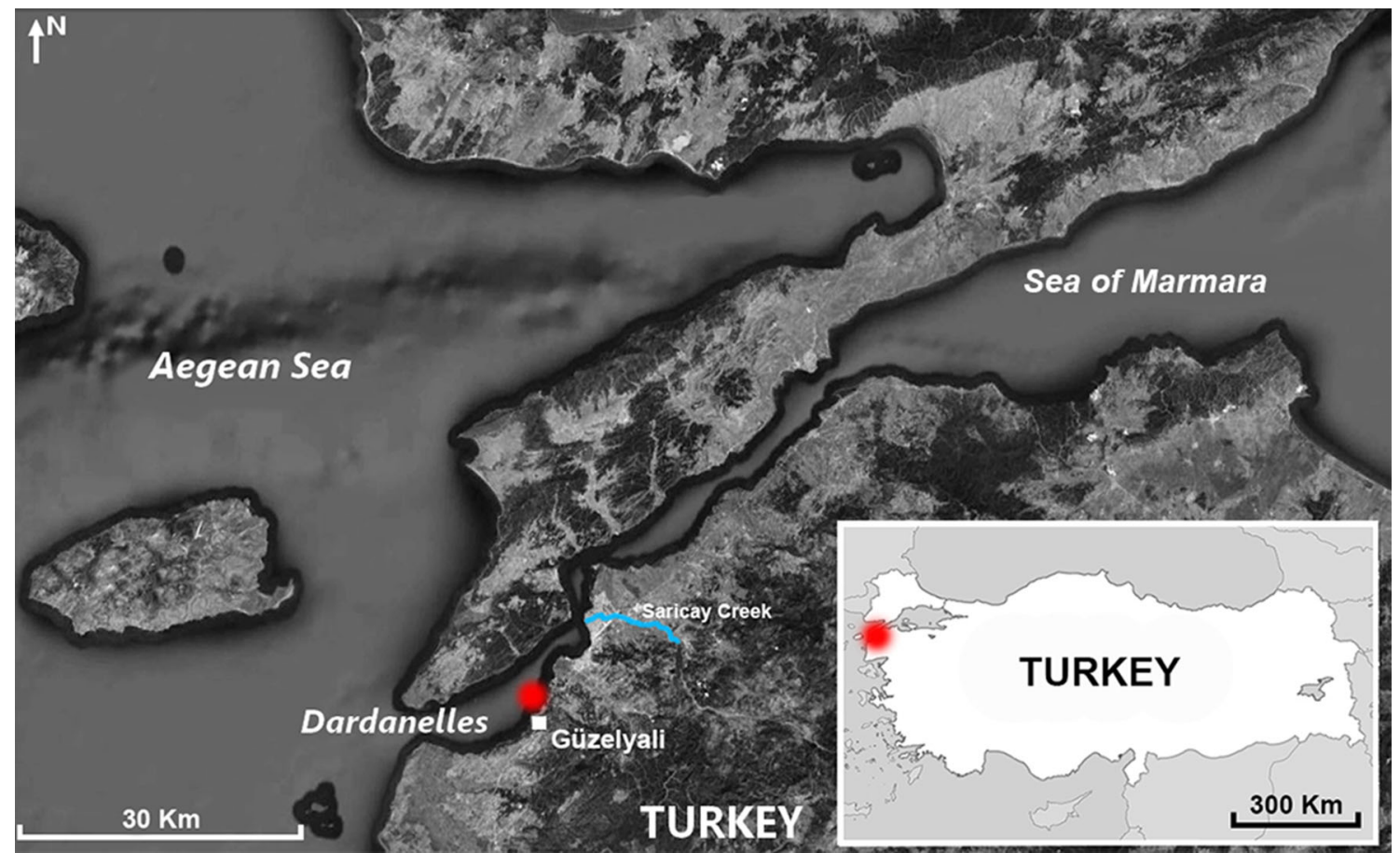

Fig. 1 Map of Turkey (small panel) indicating the site where field surveys were carried out (Güzelyali region, the Dardanelles: $40^{\circ} 02^{\prime} 04^{\prime \prime} \mathrm{N}$, $26^{\circ} 20^{\prime} 02^{\prime \prime} \mathrm{E}$, large panel) 


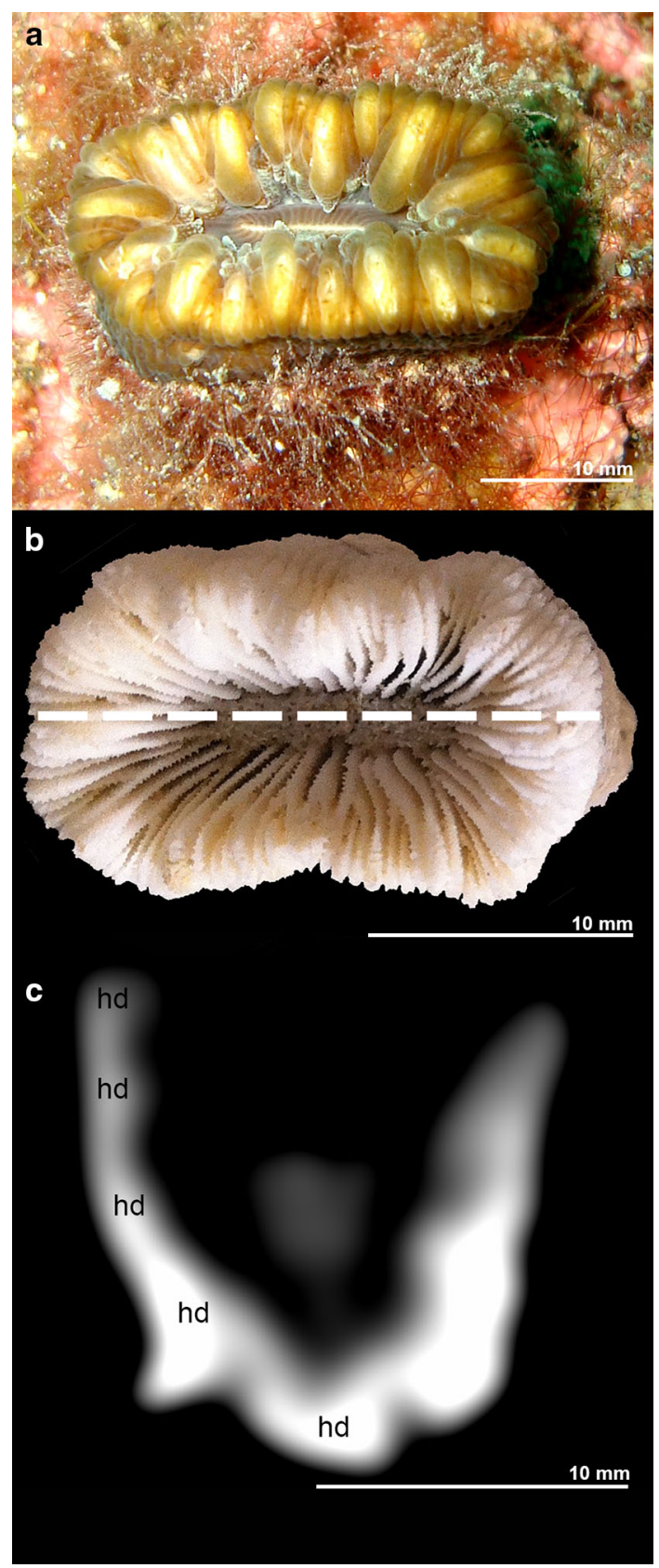

Fig. 2 Living specimen (a), skeleton (b) and computerized tomography scan (c) of Balanophyllia europaea. Dotted line in b indicates polyp length ( $L=$ maximum axis of the oral disc). Age was determined by counting the high density growth bands (hd). In this sample, the skeleton is 5 yrs old

bands were clearly distinguishable (Fig. 2c; Goffredo et al. 2008). This technique is commonly used in tropical (e.g., Bosscher 1993; Helmle et al. 2000) and temperate scleractinians (e.g., Caroselli et al. 2012, 2016), including $B$. europaea (e.g., Goffredo et al. 2004, 2008). Mean annual skeletal growth rate (linear extension rate) was estimated by dividing polyp length by its age. Mean annual net calcification rate (amount of $\mathrm{CaCO}_{3}$ deposited each year per area unit) was obtained as net calcification rate $\left(\mathrm{mg} \mathrm{mm} \mathrm{m}^{-2} \mathrm{yr}^{-1}\right)=$ bulk skeletal density $\left(\mathrm{mg} \mathrm{mm}^{-3}\right) \times-$ linear extension rate $\left(\mathrm{mm} \mathrm{yr}^{-1}\right)$, a formula commonly used both for reef-building (Lough and Barnes 2000; CarricartGanivet 2004) and solitary corals (e.g., Goffredo et al. 2009; Caroselli et al. 2012, 2016).

Modeling the relationship between age and length allows to compare the skeletal growth pattern among populations and to estimate the age of a sample for which CT scan analysis was not performed, as required for demographic analyses currently underway. Mean annual skeletal growth rate was negatively exponentially related to individual age, as reported for B. europaea (Goffredo et al. 2008) and other Mediterranean solitary corals along Italian coasts (Caroselli et al. 2012, 2016), This allowed to apply the von Bertalanffy growth model (von Bertalanffy 1938):

$L_{t}=L_{\infty}\left(1-\mathrm{e}^{-k t}\right)$

where $L_{t}$ is individual length at age $t, L_{\infty}$ is the asymptotic length (maximum expected length in the population), $k$ is a growth constant and $t$ is the age of the individual. Values of $L_{\infty}$ and $k$, with their confidence intervals $(\mathrm{CI})$, were estimated for each depth through a regression analysis by least squares procedure developed in the software MATLAB R2012a (MathWorks, Natick, USA) using raw data of polyp length and age (measured by CT; see Caroselli et al. 2016), since this method has better fitting properties than traditional methods (Sparre and Venema 1998).

\section{Skeletal parameters}

To obtain skeletal parameters (bulk density, micro-density, porosity) of collected corals, buoyant weight measurements were performed using the density determination kit of the Ohaus Explorer Pro Balance. The standard balance's pan was replaced by a suspended weighing support attached to an underwater weighing pan submerged in a glass beaker filled with distilled water. Corals were placed in a desiccator connected to a vacuum pump for about $1 \mathrm{~h}$ to suck out water and air from the pores. Then, still under vacuum, the dried corals were soaked by gradually pouring distilled water inside the desiccator ensuring that no air bubble formed on their surfaces. This simple and non-destructive method has been widely used on various corals and allows to obtain skeletal parameters after some calculations (details in ESM 1; Barnes and Devereux, 1988; Caroselli et al. 2011).

\section{Temperature data}

During 2013 and 2015, sea surface temperature (SST) and depth temperature (DT) were simultaneously measured 
once per month by divers at the sampling site, using mercury thermometers $\left( \pm 0.1^{\circ} \mathrm{C}\right)$. This timing is not sufficient to accurately characterize daily variation of temperature at each depth. However, the trend of measured temperatures and the differences among depths are consistent between the 2 yrs (ESM 2) and can be useful as proxies of average temperature differences among depths and how they vary through the year. Sea surface temperature (SST; ${ }^{\circ} \mathrm{C}$ ) data for the period 2010-2015 were obtained from NASA Earth Observations (https://neo.sci. gsfc.nasa.gov). Mean annual SST values were computed from monthly measurements. A linear regression was obtained between DT and SST data to estimate at-depth temperatures during 2010-2015.

\section{Statistical analyses}

An analysis of variance (ANOVA) was used to compare mean length, width, micro-density, bulk density, porosity, linear extension rate, and net calcification rate among depths. The non-parametric Kruskal-Wallis test was used to compare mean height, volume, and mass among the three depths as an alternative to ANOVA that does not assume normality of data, as the test is based on data ranks. This test proved to be more robust than its counterpart in the case of non-normal distribution of sample data (Potvin and Roff 1993). Post hoc tests after an ANOVA provide specific information on which means are significantly different from each other. Tukey's HSD and Scheffe's post hoc tests were used to test differences in skeletal parameters among the three depths. All analyses were computed using SPSS Statistics 20.0.

\section{Results}

\section{Biometry}

Polyp length (Fig. 2b) was chosen as the main biometric parameter since it is a good indicator of skeletal mass and has been used to represent polyp size in biometric (Goffredo et al. 2004), reproductive biology (Goffredo et al. 2002), skeletal growth (Goffredo et al. 2009; Fantazzini et al. 2015) and population dynamics studies of B. europaea (Goffredo et al. 2008) and other temperate (Bell and Turner 2000) and tropical solitary corals (Hoeksema 1991; Goffredo and Chadwick-Furman 2003).

Polyp width, height, volume and skeletal mass correlated positively with polyp length, while bulk skeletal density was correlated with polyp length only at $11 \mathrm{~m}$ depth (Fig. 3). Each relationship between biometric parameters and polyp length was linearized and the obtained slopes (the original equation exponent) and intercepts (the natural logarithm of the original factor) were compared among study sites. Factors and exponents of the $W / L$ relationships were homogeneous (their confidence intervals, CI, were overlapped; Table 1; Fig. 3), then data were pooled to obtain a general $W / L$ relationship across depths. All other biometric relationships significantly differed among depths (the CIs of their exponents and factors were not overlapped; Table 1; Fig. 3). Mean length and width of samples were homogeneous across depths (ANOVA, $p>0.05$ ), while mean height, volume, and mass were significantly different (Kruskal-Wallis test, $p<0.05$ ). Corals increased their mean height, volume, and mass with increasing depth (Table 2).

\section{Skeletal growth}

Mean skeletal growth rate at each depth decreased exponentially with age (Fig. 4), whose variation explained $16-57 \%$ of growth rate variance (Fig. 4). On average, skeletal growth rate decreased from $3.1 \mathrm{~mm} \mathrm{yr}^{-1}$ (CI 2.8-3.4) at age $<5$ yrs to $2.4 \mathrm{~mm} \mathrm{yr}^{-1}$ (CI 2.3-2.5) between 5 and $10 \mathrm{yrs}$, to $1.8 \mathrm{~mm} \mathrm{yr}^{-1}$ (CI 1.4-2.2) at age $>10 \mathrm{yrs}$ (Fig. 4). By linearizing the exponential growth curves, slopes and intercepts were compared among the three depths and with the general one (Table 3). The CI of slopes and intercepts overlapped with that of the general values (Table 3), indicating homogeneous exponential curves among depths, as well as the estimated $L_{\infty}$ and $k$ values of the respective von Bertalanffy growth curves (Fig. 4; Table 3). Thus, age-length data from growth bands at all depths were pooled obtaining a general $L_{\infty}=25.6 \mathrm{~mm}(21.8-29.5 \mathrm{~mm}, 95 \% \mathrm{CI})$ and a general $k=0.148(0.110-0.187,95 \% \mathrm{CI}$; Table 3$)$. According to the model, young individuals ( $1-3$ yrs old) grew relatively rapidly $\left(2.3-3.5 \mathrm{~mm} \mathrm{yr}^{-1}\right)$, but, as they aged, their skeletal growth rate decreased $\left(0.8-1.1 \mathrm{~mm} \mathrm{yr}^{-1}\right.$ at $8-10$ yrs old), and by the time they were $17-20$ yrs old, grew only $0.2-0.3 \mathrm{~mm} \mathrm{yr}^{-1}$ (Fig. 4).

Net calcification rate was positively correlated with linear extension rate $(p<0.001)$, but no correlation was found between bulk skeletal density and net calcification rate $(p>0.05)$ nor between bulk skeletal density and linear extension rate $(p>0.05)$. Bulk skeletal density differed among depths (ANOVA, $p<0.001$ ), while linear extension and net calcification rate were homogeneous (ANOVA, $p>0.05$; Table 4).

\section{Skeletal parameters}

Bulk skeletal density correlated negatively with porosity at all depths (Fig. 5). Micro-density was slightly and positively correlated with bulk density and porosity at $1 \mathrm{~m}$ 

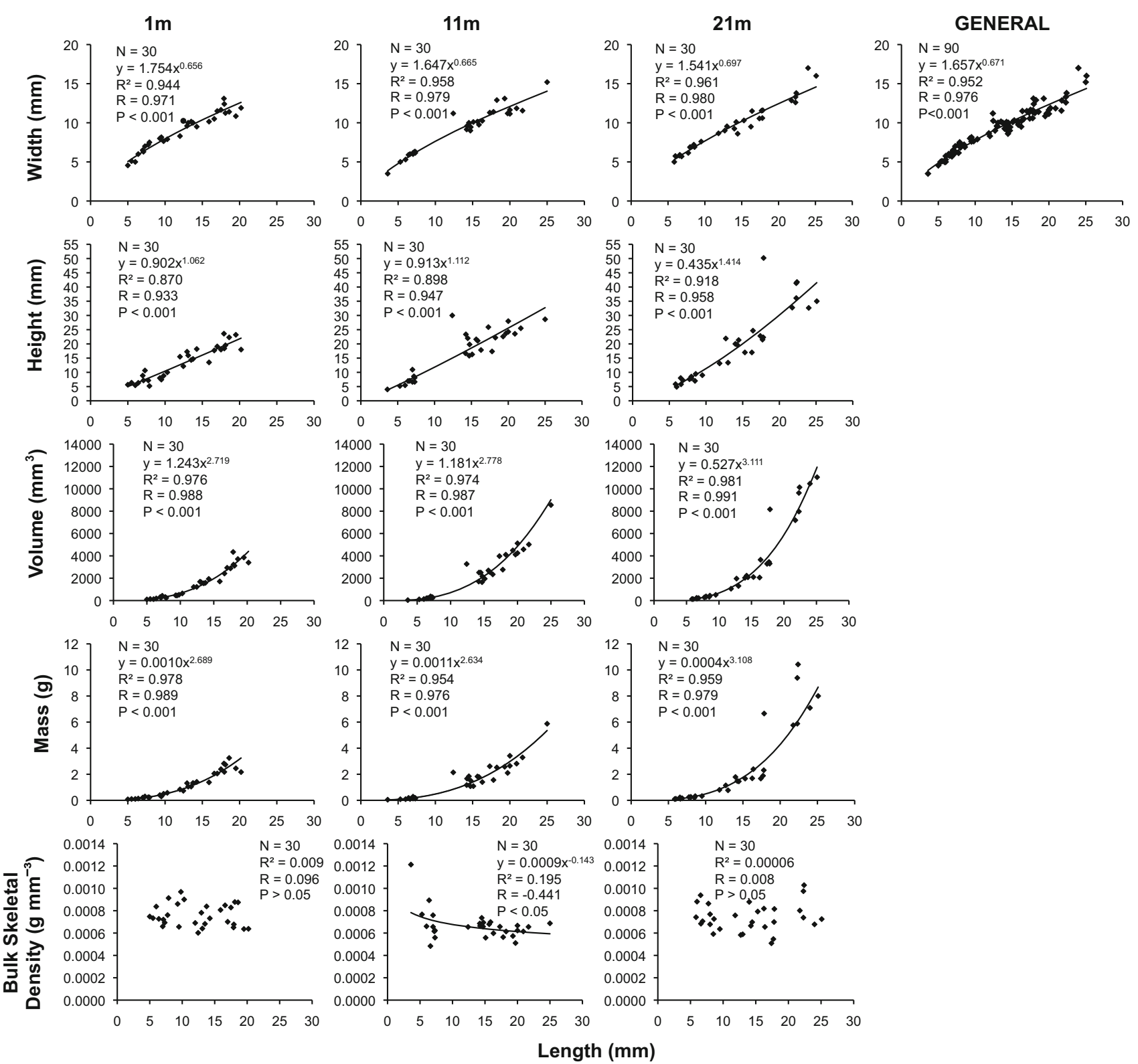

Fig. 3 Balanophyllia europaea. Relationships between biometric parameters and individual length of collected samples at the three depths. Width/length data were pooled to obtain a general relationship

depth and with bulk density at $11 \mathrm{~m}$ depth (Fig. 5). No other correlation was found between skeletal parameters.

No skeletal parameter was correlated with age, except for two statistically significant but almost horizontal relationships between micro-density and age at 11 and $21 \mathrm{~m}$ (ESM 3). Mean skeletal parameters differed among depths (ANOVA, micro-density: $p<0.001$; bulk density: $p<0.001$; porosity: $p<0.01$; Table 5; Fig. 6). The $1-\mathrm{m}$ depth group was significantly different compared to 11and $21-\mathrm{m}$ depth groups (post-hoc tests, $p<0.001$ for bulk and micro-density; $p<0.05$ for porosity). Individuals at $1 \mathrm{~m}$ depth were statistically more porous and less dense because the curves of the single depths were homogeneous. $N$, number of samples; $R^{2}$, Pearson's coefficient of determination; $R$, Pearson's correlation coefficient

both in bulk density and micro-density than individuals at deeper depths (Table 5; Fig. 6). However, bulk density and micro-density at $1 \mathrm{~m}$ were only 10 and $<5 \%$ lower, respectively, than at 11 and $21 \mathrm{~m}$ depth.

\section{Discussion}

This is the first investigation of skeletal growth and skeletal parameters of a scleractinian coral across a depth gradient in the Mediterranean Sea. It also expands eastward the recorded longitudinal range of this species with 11 degrees, 
Table 1 Balanophyllia europaea. Regression coefficients of the biometric relationships of collected samples at the three depths

\begin{tabular}{lllll}
\hline Dependent variable & Depth & $N$ & Exponent $(\mathrm{CI})$ & Factor $(\mathrm{CI})$ \\
\hline$W(\mathrm{~mm})$ & $1 \mathrm{~m}$ & 30 & $0.656(0.594-0.718)$ & $1.754(1.507-2.044)$ \\
& $11 \mathrm{~m}$ & 30 & $0.666(0.612-0.719)$ & $1.647(1.436-1.889)$ \\
& $21 \mathrm{~m}$ & 30 & $0.697(0.643-0.752)$ & $1.541(1.340-1.772)$ \\
& General & 90 & $0.671(0.639-0.702)$ & $1.657(1.616-1.699)$ \\
$h(\mathrm{~mm})$ & $1 \mathrm{~m}$ & 30 & $1.063(0.904-1.222)$ & $0.902(0.609-1.335)$ \\
& $11 \mathrm{~m}$ & 30 & $1.112(0.967-1.257)$ & $0.913(0.630-1.323)$ \\
& $21 \mathrm{~m}$ & 30 & $1.414(1.251-1.577)$ & $0.436(0.286-0.664)$ \\
$V\left(\mathrm{~mm}^{3}\right)$ & $1 \mathrm{~m}$ & 30 & $2.719(2.554-2.884)$ & $1.243(0.829-1.866)$ \\
& $11 \mathrm{~m}$ & 30 & $2.778(2.602-2.953)$ & $1.181(0.754-1.848)$ \\
& $21 \mathrm{~m}$ & 30 & $3.111(2.946-3.277)$ & $0.527(0.344-0.808)$ \\
$M(\mathrm{~g})$ & $1 \mathrm{~m}$ & 30 & $2.689(2.533-2.845)$ & $0.0010(0.0007-0.0015)$ \\
& $11 \mathrm{~m}$ & 30 & $2.635(2.410-2.859)$ & $0.0011(0.0006-0.0020)$ \\
& $21 \mathrm{~m}$ & 30 & $3.109(2.863-3.354)$ & $0.0004(0.0002-0.0007)$ \\
\hline
\end{tabular}

Length $(\mathrm{mm})$ is the independent variable. Data were fitted to a power function model $y=a x^{\mathrm{b}}$. The factor " $a$ " and the exponent " $b$ " are indicated together with their confidence interval. $N$ number of samples

\begin{tabular}{lcccc}
\hline & $1 \mathrm{~m}$ & $11 \mathrm{~m}$ & $21 \mathrm{~m}$ & General \\
\hline$L(\mathrm{~mm})$ & $12.3(10.5-14.1)$ & $13.7(11.5-15.9)$ & $13.9(11.7-16.2)$ & $13.3(12.2-14.5)$ \\
$W(\mathrm{~mm})$ & $8.9(8.1-9.8)$ & $9.2(8.1-10.3)$ & $9.5(8.4-10.7)$ & $9.2(8.7-9.8)$ \\
$H(\mathrm{~mm})$ & $13.3(11.1-15.4)$ & $17.2(14.1-20.2)$ & $19.5(14.8-24.2)$ & \\
$V\left(\mathrm{~mm}^{3}\right)$ & $1553(1057-2050)$ & $2415(1645-3185)$ & $3210(1865-4555)$ & \\
$M(\mathrm{~g})$ & $1.15(0.79-1.52)$ & $1.54(1.04-2.05)$ & $2.49(1.34-3.63)$ & \\
\hline
\end{tabular}

The "general" values are the means across all depths
Table 2 Mean biometric parameters together with their confidence intervals $(\mathrm{CI})$ at the three depths easily carried out by gravity (Stafford-Smith and Ormond 1992; Caroselli et al. 2015b).

The exponents of the $\mathrm{h} / \mathrm{L}$ relationship at 1 and $11 \mathrm{~m}$ in the Dardanelles (0.904-1.257; Table 1) were similar to those observed in the Italian populations at $6 \mathrm{~m}$ (0.971-1.364; Goffredo et al. 2007), while the exponent at $21 \mathrm{~m}$ (1.251-1.577; Table 1) was slightly higher. Also mean height increased with depth (Table 2). Organisms growing in shallow waters are more influenced by strong wave action than those living in deeper waters and this could lead to a weak vertical extension rate (Smith and Harrison 1977; Adey 1978). The observed increase of height with depth in B. europaea could be linked to the above-mentioned stronger wave action at shallower depths. Light intensity variations associated with depth may also determine the decrease in coral height at shallow depth. Some coral species (e.g., the tropical Montipora verrucosa and Stylophora pistillata) have impressive phenotypic plasticity capabilities and allowed to test the effect of light on colony morphology through observations on natural populations and through cross-transplant experiments on clonal fragments (Einbinder et al. 2009; Iluz and Dubinsky 2015). Corals growing in high light conditions (i.e., shallow depth) typically show massive morphologies or thick 


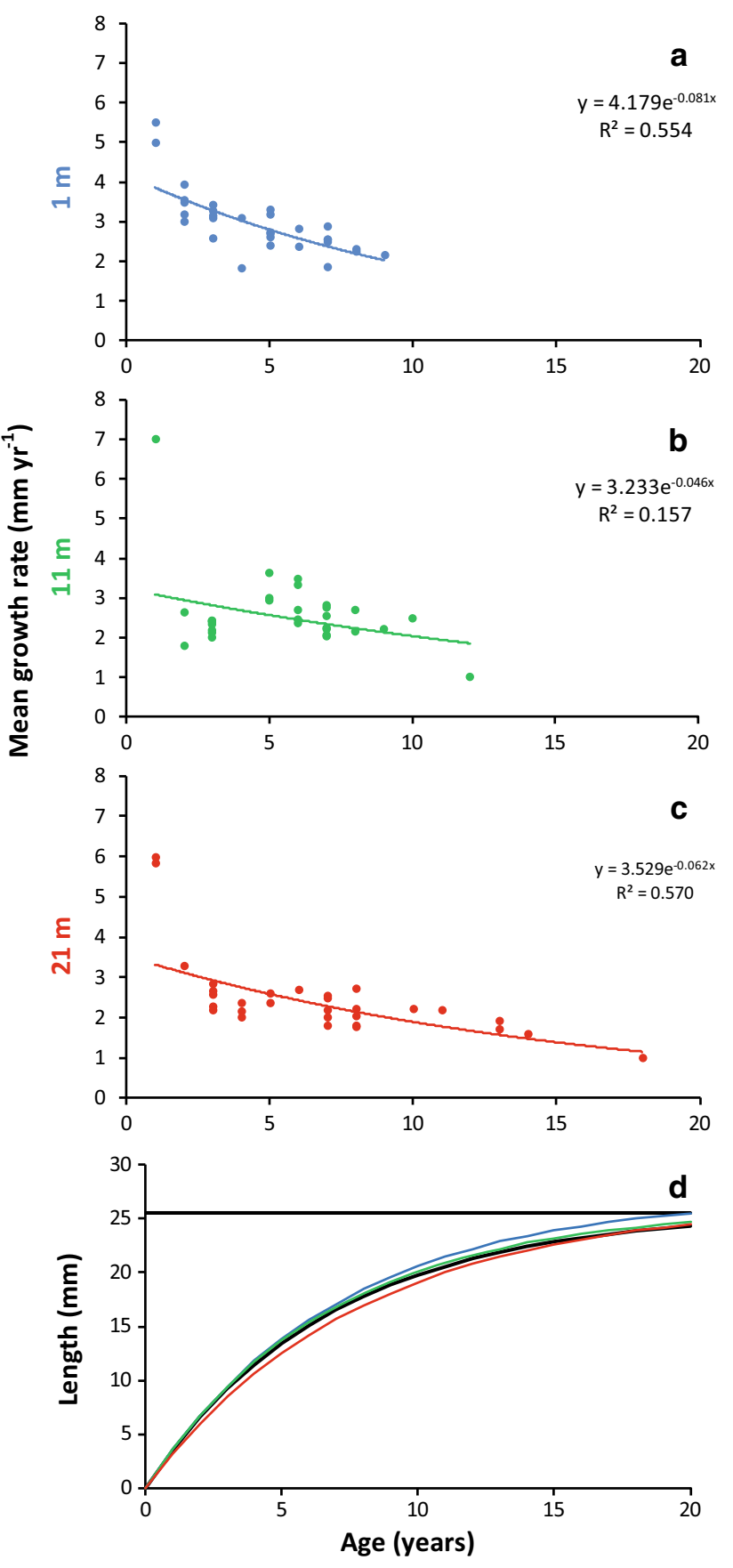

Fig. 4 Relationships between mean skeletal growth rate and age of collected corals at the three depths $(\mathbf{a}-\mathbf{c})$ and age-length von Bertalanffy growth curves at each depth with general growth curve across all depths (d)

branches while conspecifics living in low light conditions (i.e., deeper depth) have plate-like morphologies or thin and profused branches (Todd 2008; Einbinder et al. 2009; Iluz and Dubinsky 2015). This has been interpreted as a photoprotective strategy at shallow depth and a light-harvesting-maximization strategy at deeper depth (Iluz and Dubinsky 2015). The decrease of coral height at shallow
Table 3 Exponents and factors of the exponential growth curves and $L_{\infty}$ and $K$ values of the von Bertalanffy growth curves at each depth together with their $95 \%$ confidence intervals $(\mathrm{CI})$

\begin{tabular}{lcl}
\hline & Exponent $(\mathrm{CI})$ & Factor $(\mathrm{CI})$ \\
\hline $1 \mathrm{~m}$ & $-0.081(-0.108$ to -0.053$)$ & $4.179(3.625$ to 4.816$)$ \\
$11 \mathrm{~m}$ & $-0.046(-0.088$ to -0.005$)$ & $3.233(2.509$ to 4.166$)$ \\
$21 \mathrm{~m}$ & $-0.062(-0.083$ to -0.041$)$ & $3.529(2.995$ to 4.154$)$ \\
General & $-0.065(-0.080$ to -0.050$)$ & $3.687(3.343$ to 4.067$)$ \\
\hline & $K(\mathrm{CI})$ & $L_{\infty}(\mathrm{CI})$ \\
\hline $1 \mathrm{~m}$ & $0.143(0.074$ to 0.212$)$ & $27.1(18.6$ to 35.5$)$ \\
$11 \mathrm{~m}$ & $0.149(0.038$ to 0.261$)$ & $26.0(14.6$ to 37.4$)$ \\
$21 \mathrm{~m}$ & $0.128(0.077$ to 0.180$)$ & $26.5(20.6$ to 32.4$)$ \\
General & $0.148(0.110$ to 0.187$)$ & $25.6(21.8$ to 29.5$)$ \\
\hline
\end{tabular}

General values are also indicated

depth that we observed in this study makes the coral more massive and indeed this may be related to a photoprotective response. Alternatively, the Sarç̧ay Creek (Fig. 1) that flows almost into the middle of the Dardanelles may promote higher polyps in deeper waters. Since the current direction at the mouth of the creek flows to the Aegean Sea, the creek waters that are exposed to domestic charges, sewage inputs and agricultural runoffs (Pamukcu et al. 2014) head south with the stream towards our sampling site (Fig. 1). At this region, the substrate below the Posidonia lower limit (ca. $17 \mathrm{~m}$ depth) is mainly composed of deadmild muddy soil (Özalp and Alparslan 2011) and corals may grow taller to outgrow the accumulation of sediment, as reported for other cup corals (e.g., Bell and Turner 2000). The morphology of several coral species is reported to influence their ability to tolerate sedimentation stress (reviewed in Erftemeijer et al. 2012).

\section{Skeletal growth}

Many colonial scleractinians grow indeterminately (Hughes and Jackson 1985; Bak and Meesters 1998), but some corals reduce their growth rate as they age, such as Pocillopora spp. (Grigg and Maragos 1974), Coelastrea aspera (Sakai 1998; Huang et al. 2014), and Manicina areolata (Johnson 1992). Determined growth is mainly found in solitary corals, such as B. europaea (Goffredo et al. 2008), B. elegans, Paracyathus stearnsii (Gerrodette 1979), Leptopsammia pruvoti (Goffredo et al. 2010; Caroselli et al. 2012), C. inornata (Caroselli et al. 2016), Flabellum alabastrum (Hamel et al. 2010), and mushroom coral species (e.g., Yamashiro and Nishihira 1998; Goffredo and Chadwick-Furman 2003; Elahi and Edmunds 2007; Knittweis et al. 2009; Gittenberger et al. 2011). 
Table 4 Mean bulk skeletal density, linear extension rate and net calcification rate with the $95 \%$ confidence intervals (CI) at the three depths

\begin{tabular}{llll}
\hline & $1 \mathrm{~m}$ & $11 \mathrm{~m}$ & $21 \mathrm{~m}$ \\
\hline Linear extension rate $\left(\mathrm{mm} \mathrm{yr}^{-1}\right)$ & $2.98(2.68-3.28)$ & $2.62(2.26-2.99)$ & $2.47(2.08-2.86)$ \\
Bulk skeletal density $\left(\mathrm{mg} \mathrm{mm}^{-3}\right)$ & $1.92(1.88-1.96)$ & $2.14(2.09-2.19)$ & $2.10(2.04-2.16)$ \\
Net calcification rate $\left(\mathrm{mg} \mathrm{mm}^{-2} \mathrm{yr}^{-1}\right)$ & $5.69(5.16-6.22)$ & $5.59(4.87-6.32)$ & $5.17(4.44-5.89)$ \\
\hline
\end{tabular}

$11 \mathrm{~m}$
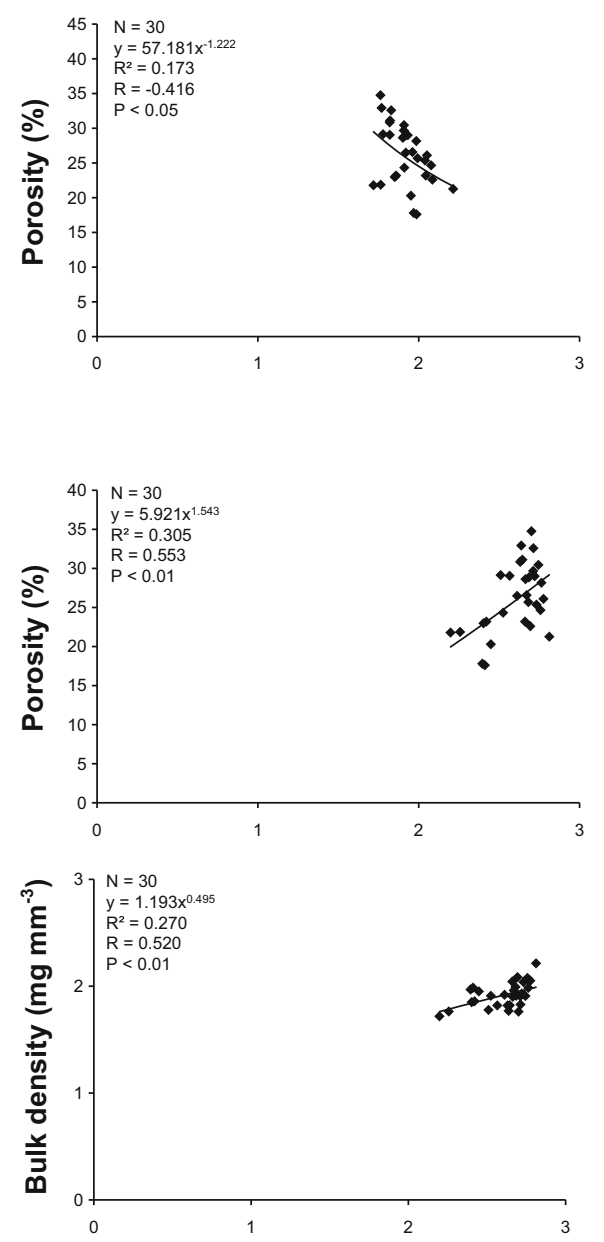
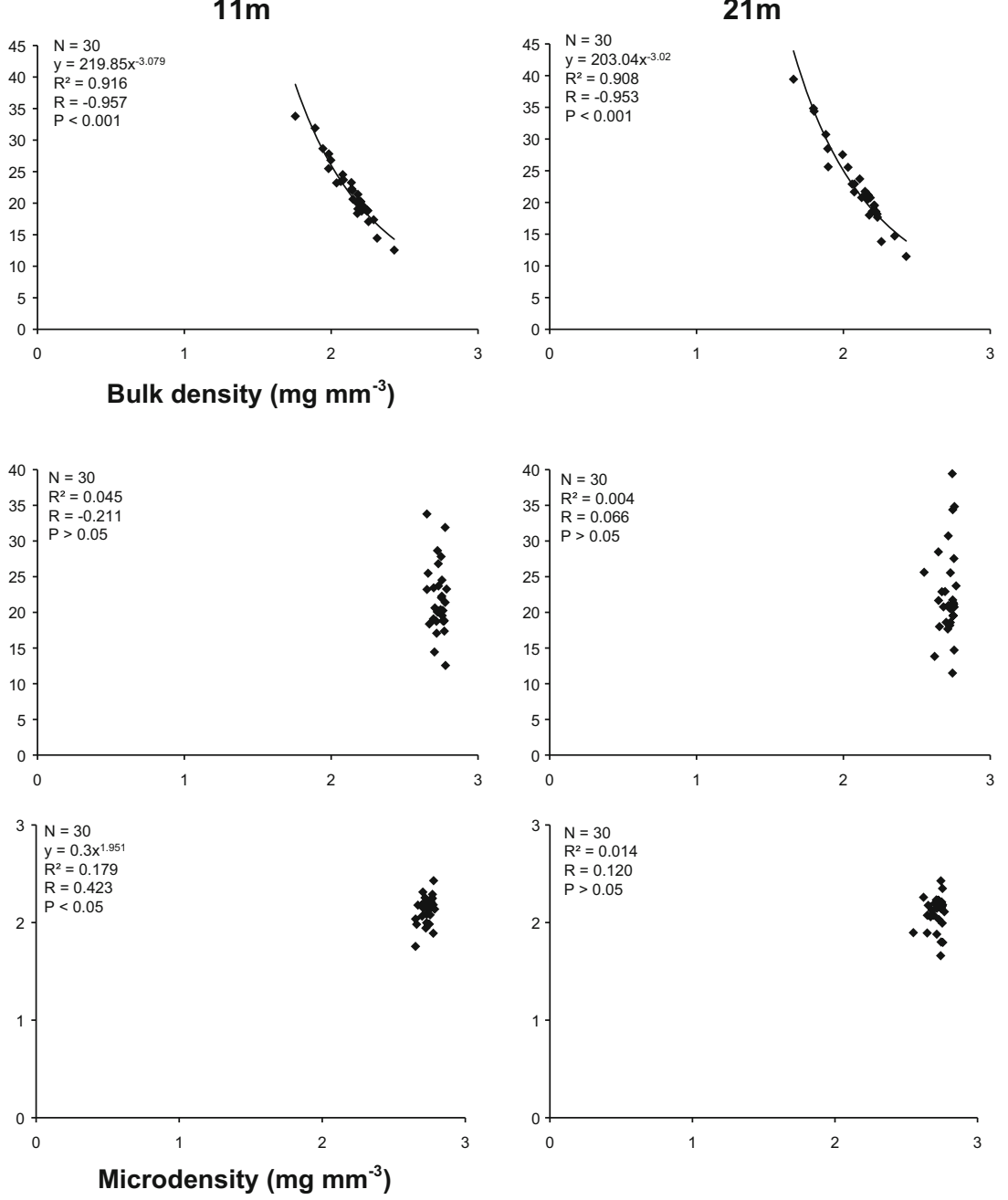

Fig. 5 Regression and correlation analyses between skeletal parameters of Balanophyllia europaea at the three depths. $N$, number of samples; $R^{2}$, Pearson's coefficient of determination; $R$, Pearson's correlation coefficient

Table 5 Mean skeletal parameters together with their confidence intervals $(\mathrm{CI})$ at the three depths

\begin{tabular}{llll}
\hline & $1 \mathrm{~m}$ & $11 \mathrm{~m}$ & $21 \mathrm{~m}$ \\
\hline Micro-density $\left(\mathrm{mg} \mathrm{mm}^{-3}\right)$ & $2.60(2.54-2.66)$ & $2.73(2.72-2.75)$ & $2.71(2.69-2.73)$ \\
Bulk density $\left(\mathrm{mg} \mathrm{mm}^{-3}\right)$ & $1.92(1.88-1.96)$ & $2.14(2.09-2.19)$ & $2.10(2.04-2.16)$ \\
Porosity (\%) & $26.2(24.6-27.9)$ & $21.8(20.0-23.5)$ & $22.5(20.2-24.8)$ \\
\hline
\end{tabular}

Polyps of B. europaea reduced their skeletal growth rate with age at all studied depths, as in NW Mediterranean populations (Goffredo et al. 2004, 2008, 2009; Fantazzini et al. 2015). The maximum individual length predicted for all depths $\left(L_{\infty}=25.6 \mathrm{~mm}\right)$ is very close to that of a study site at similar latitude in the western Mediterranean Sea (Palinuro, $40^{\circ} 02^{\prime} \mathrm{N}, L_{\infty}=25.5 \mathrm{~mm}$; Goffredo et al. 2008), suggesting that the relationship between maximum size and temperature associated with latitude observed along Italian coasts may be conserved also in the Eastern Mediterranean 

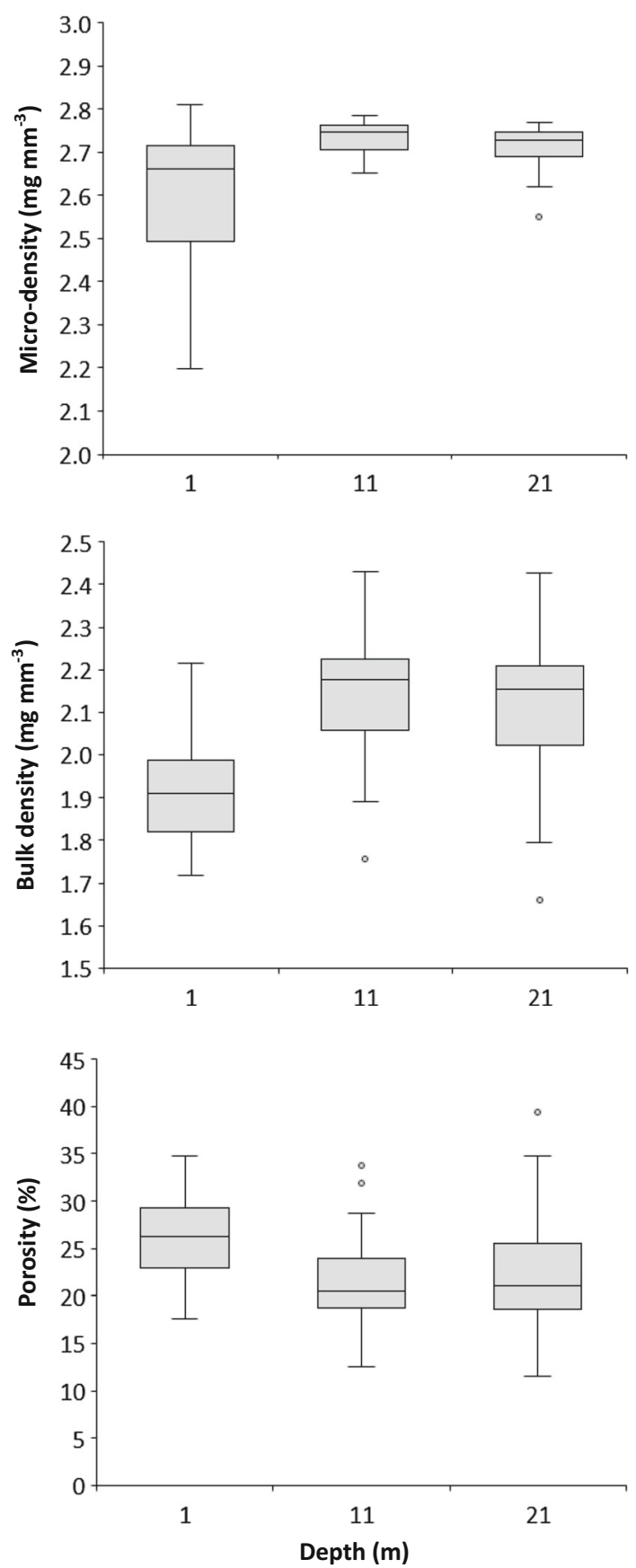

Fig. 6 Boxplots of skeletal parameters at each depth. Median (solid horizontal line), first and third quartiles (box outline), and outliers (circles)

Sea, leading to similar maximum body size at similar latitudes.

Corals can preferentially invest calcification resources in increasing bulk skeletal density or accelerating linear extension rate, or both. Tropical zooxanthellate corals show different strategies. Porites sp. invests calcification resources into linear extension (Lough and Barnes 2000), while Orbicella annularis allocates them into bulk skeletal density (Carricart-Ganivet 2004). Along Italian coasts at $6 \mathrm{~m}$ depth, B. europaea allocates calcification evenly between linear extension and skeletal density, thus balancing the mechanical resistance of the skeleton and the ability to colonize the substratum quickly (Goffredo et al. 2009). In the Dardanelles, instead, B. europaea allocates calcification resources more in linear extension rate than in increasing bulk skeletal density. The possible gains acquired in the Dardanelles by rapid linear extension at the expenses of skeletal density need to be characterized in further studies, but a possible explanation may be related to the enclosed character of the strait and consequent lower wave activity. In contrast, along Italian coasts wave action can be very strong, especially in winter, and strengthening the skeleton by increasing its density may be more important for polyp survival. While in tropical colonial corals skeletal density is less important than colony architecture in determining skeletal resistance to breakage (Marhsall 2000), nanoindentation analyses of the relatively simple and solitary corallites of B. europaea have reported a strong correlation between bulk skeletal density and stiffness (Goffredo et al. 2015). It is noteworthy that some solitary tropical mushroom corals decalcify their skeleton along radial slits in order to facilitate fragmentation and dispersal (Hoeksema and Waheed 2011).

Corals showed a higher calcification rate (mean net calcification rate across depths $=5.48 \mathrm{mg} \mathrm{mm}^{-2} \mathrm{yr}^{-1}$; Table 4) than populations of B. europaea in the western Mediterranean (mean net calcification rate among sites $=1.45 \mathrm{mg} \mathrm{mm}^{-2} \mathrm{yr}^{-1}$; maximum net calcification rate $($ Calafuria $)=2.86 \mathrm{mg} \mathrm{mm}^{-2} \mathrm{yr}^{-1}$; Goffredo et al. 2009) with an increment of $278 \%$ between means of the two regions and an increment of $92 \%$ between the Dardanelles and Calafuria. Since net calcification rate of this species is inversely related to temperature (Goffredo et al. 2009) the exceptionally high calcification rate in the Dardanelles could be expected as related to a lower mean annual temperature at this region. However, this is not the case, as the temperature regime at the Dardanelles and at Calafuria is very similar both as mean and as annual range (ESM 2 and 3). Also solar radiation, which is highly dependent on latitude, is unlikely to determine this difference, because the latitude of the Dardanelles study site is included in the latitudinal range of investigated NW Mediterranean populations (Goffredo et al. 2007). Different energy investment trade-offs between skeletal growth and reproduction between the Dardanelles and Calafuria may be also be responsible for the different calcification rate and, thus, further investigations on reproductive parameters (e.g., fecundity) and on the dynamics of environmental parameters in the Dardanelles are required to clarify this issue. This also underlines the importance of integrating skeletal growth data with other biological 
aspects, such as reproductive information of the populations, when assessing their response to environmental changes.

Linear extension and net calcification rates were homogeneous among depths. This could be related to the combined effect of light and temperature. Calcification of zooxanthellate corals is modulated by the light utilization strategies of symbiotic zooxanthellae (Dustan 1982). Light generally stimulates photosynthesis, until light saturation is reached, and further increases can negatively influence coral growth rate (Caroselli et al. 2015a). In this study, light intensity decreased with depth, likely causing a decrease in photosynthesis rate. However, temperature was higher at shallow depth (ESM 2 and 3), thus leading to photosynthesis inhibition (Brown and Cossins 2011; Caroselli et al. 2015a). At shallow depths, a higher light level (positive effect) could balance the higher temperature (negative effect), while at deeper depths, a lower level of light (negative effect) could balance the lower temperature (positive effect). Thus, a compensation between the two effects may lead to the homogeneous linear extension and net calcification rates among depths. A similar response has already been observed in some tropical colonial corals that calcify more rapidly at intermediate than at shallow and deeper depths (e.g., Montastraea annularis, Baker and Weber 1975; M. cavernosa, Huston 1985). The difference of just $1{ }^{\circ} \mathrm{C}$ in mean annual temperature between 1 and $21 \mathrm{~m}$ depth may seem slight for a temperate species that is adapted to wide annual temperature fluctuations. However, when looking at the temperature time series (ESM 2), a striking difference in temperature range is observed between $1 \mathrm{~m}\left(10.8-26.9^{\circ} \mathrm{C}\right)$ and $21 \mathrm{~m}\left(15.5-19.6^{\circ} \mathrm{C}\right)$. Shallow depths are subject to temperatures up to $7^{\circ} \mathrm{C}$ higher than those recorded at $21 \mathrm{~m}$. Since $B$. europaea photosynthesis is negatively affected by high temperatures (Caroselli et al. 2015a), it seems reasonable that shallow water populations are stressed by high temperatures at least in the hottest summer months, while deeper populations never experience such high temperature conditions. In the more thermally stable tropical reef environment, corals generally live close to their upper temperature tolerance (Jokiel and Coles 1990) and their response to temperature differences may be even more pronounced (e.g., MaorLandaw et al. 2017). Analyses along depth gradients on tropical reef corals may help to assess if deeper populations may represent potential micro-refugia from global warming effects (Kleypas et al. 2008; Bridge et al. 2014).

\section{Skeletal parameters}

As in Italian populations, this study confirms the strong negative correlation between skeletal bulk density and porosity and the almost absent correlation between skeletal parameters and age (Caroselli et al. 2011), which seems a common feature of tropical (e.g., Bucher et al. 1998) and temperate scleractinian corals (e.g., Caroselli et al. 2011; Fantazzini et al. 2015; Fig. 5 and ESM 4). Even if calcification resources were preferentially allocated into linear extension, in the Dardanelles corals were less porous and denser than in NW Mediterranean basin, as mean porosity range of Dardanelles populations (20.2-27.9\%; Table 5; Fig. 6) was lower than in Italian populations (29.6-38.2\%; Caroselli et al. 2011). This higher bulk density seems related to the exceptionally high net calcification rate in the Dardanelles with respect to NW Mediterranean populations, already discussed above. A remarkable higher variability around the negative relationship between porosity and bulk density was observed at $1-\mathrm{m}$ depth relative to 11 and 21-m depth (Fig. 5), likely resulting from the lower environmental stability in shallow waters.

Variations in micro-density, even if statistically significant, were not strong enough to cause significant impact on bulk density. The skeleton of scleractinian corals is a twophase material consisting of aragonitic calcium carbonate associated with an intra-crystalline organic matrix (OM; Cuif et al. 1999). OM is thought to begin the nucleation of calcium carbonate and provide a structure for crystallographic spatial orientation and species-specific architecture (Addadi and Weiner 1985; Falini et al. 2015). At 11 and $21 \mathrm{~m}$, micro-density increased only of $5.0 \%$ among the age extremes at $11 \mathrm{~m}$, and only of $8.5 \%$ at $21 \mathrm{~m}$. A decrease of intra-crystalline OM content with increasing age, which has been previously hypothesized (Goffredo et al. 2015), could explain this slight increase of micro-density with age (Caroselli et al. 2011). An increase in OM content can instead be responsible for the lower range of values of micro-density at $1 \mathrm{~m}\left(2.20-2.81 \mathrm{mg} \mathrm{mm}^{-3}\right)$ relative to $11 \mathrm{~m} \quad\left(2.65-2.79 \mathrm{mg} \mathrm{mm}^{-3}\right)$ and $21 \mathrm{~m} \quad(2.55-2.77$ $\mathrm{mg} \mathrm{mm}{ }^{-3}$; Fig. 5). Based on the deviation from the density of pure aragonite (2.94 $\mathrm{mg} \mathrm{mm}^{-3}$; Bucher et al. 1998), observed micro-density values translate in an increased OM content range at $1 \mathrm{~m}(4-25 \%)$ relative to $11 \mathrm{~m}$ $(5-10 \%)$ and $21 \mathrm{~m}(6-13 \%$; estimated as OM \%= $1-$ micro-density/2.94). The higher OM content at $1 \mathrm{~m}$ may influence the mechanical properties of coral skeletons, which need to endure stronger current and wave regimes than in deeper waters (the average flow regime is $0.6-1.1 \mathrm{~m} \mathrm{~s}^{-1}$ at the surface and $0.5-0.6 \mathrm{~m} \mathrm{~s}^{-1}$ at $30 \mathrm{~m}$ depth; Gökaşan et al. 2008). Alternatively, different kinds of OM could be produced during the life cycle of the polyp, leading to precipitation of crystal phases with different densities, causing the observed increase of micro-density with age and the lower micro-density at $1 \mathrm{~m}$.

Skeletal porosity slightly decreased with depth, possibly favoring the mechanical resistance of the skeleton (Goffredo et al. 2015). This is in contrast with previous studies 
stating that corals growing in shallow waters are more influenced by strong wave action than corals living in deeper and calmer waters and react by developing a stronger skeleton (e.g., Adey 1978; Smith and Harrison 1977; Caroselli et al. 2011). A similar pattern has been reported in colonies of Orbicella annularis in the Virgin Islands, whose bulk density increases with depth (Baker and Weber 1975). However, it should be noted that the magnitude of skeletal bulk density increases with depth (and consequent slight decrease of porosity) is quite small (10\% variation) and is likely to have minimal biological consequence on B. europaea.

In conclusion, this study shows that (1) Biometric relationships of B. europaea in the Dardanelles were similar to Italian populations. (2) Corals were higher, with increasing depth, likely because of decreased mechanical stress from waves and water movement and/or the lower light intensity. (3) net calcification and linear extension rates were homogeneous among depths, possibly due to the combined effect of temperature and light availability variation with depth that may balance each other. (4) Notwithstanding the similar seawater temperatures, net calcification rates were higher than in Italian populations, but the driver of this increase still has to be identified and energetic trade-offs between growth and reproduction may play a role in this response. Replicating these depth-related analyses on reef corals, together with information on their reproductive and demographic traits, will enable to assess if deeper populations may help coral reefs to endure the forthcoming, increasingly warming seas.

Acknowledgements The present study was carried out under the Protocol of Bilateral Agreement between Çanakkale Onsekiz Mart University (COMU), Turkey and University of Bologna (UniBo), Italy. Financial needs for the field surveys and laboratory equipment were supported by the Faculty of Marine Science and Technology, COMU. E. Caroselli was supported by the ALMA IDEA grant of the University of Bologna for the project "STRAMICRO". We thank M. Selek and R. K. Gürses for their help during the field studies. We thank S. Durante for assistance in performing computerized tomography scans. The experiments comply with current Italian and Turkish laws.

\section{Compliance with ethical standards}

Conflict of interest On behalf of all authors, the corresponding authors state that there is no conflict of interest.

\section{References}

Addadi L, Weiner S (1985) Interactions between acidic proteins and crystals: stereochemical requirements in biomineralization. Proc Natl Acad Sci U S A 82:4110-4114

Adey WH (1978) Coral reef morphogenesis: a multidimensional model. Science 202:831-837
Arrigoni R, Kitano YF, Stolarski J, Hoeksema BW, Fukami H, Stefani F, Galli P, Montano S, Castoldi E, Benzoni F (2014) A phylogeny reconstruction of the Dendrophylliidae (Cnidaria, Scleractinia) based on molecular and micromorphological criteria, and its ecological implications. Zool Scr 43:661-688

Bak RPM, Meesters EH (1998) Coral population structure: the hidden information of colony size-frequency distributions. Mar Ecol Prog Ser 162:301-306

Baker PA, Weber JN (1975) Coral growth rate: Variation with depth. Earth Planet Sci Lett 10:135-139

Barnes DJ, Devereux MJ (1988) Variations in skeletal architecture associated with density banding in the hard coral Porites. J Exp Mar Biol Ecol 121:37-54

Bell JJ, Turner JR (2000) Factors influencing the density and morphometrics of the cup coral Caryophyllia smithii in Lough Hyne. J Mar Biol Assoc UK 80:437-441

Bongaerts P, Hoeksema BW, Hay KB, Hoegh-Guldberg O (2012) Mushroom corals overcome live burial through pulsed inflation. Coral Reefs 31:399

Bosscher H (1993) Computerized tomography and skeletal density of coral skeletons. Coral Reefs 12:97-103

Bridge TCL, Hoey AS, Campbell SJ, Muttaqin E, Rudi E, Fadil N, Baird AH (2014) Depth-dependent mortality of reef corals following a severe bleaching event: implications for thermal refuges and population recovery. F1000Research 2:187

Brown BE, Cossins AR (2011) The potential for temperature acclimatisation of reef corals in the face of climate change. In: Dubinsky Z, Stambler N (eds) Coral reefs: an ecosystem in transition. Springer Science and Business Media, Dordrecht, pp 421-433

Bucher DJ, Harriott VJ, Roberts LG (1998) Skeletal micro-density, porosity and bulk density of acroporid corals. J Exp Mar Biol Ecol 228:117-136

Buddemeier RW, Maragos JE (1974) Radiographic studies of reef coral exoskeletons: rates and patterns of coral growth. J Exp Mar Biol Ecol 14:179-200

Caroselli E, Goffredo S (2014) Mediterranean coral population dynamics: a tale of 20 years of field studies. In: Goffredo S, Dubinsky Z (eds) The Mediterranean Sea: its history and present challenges. Springer, Dordrecht, pp 275-284

Caroselli E, Falini G, Goffredo S, Dubinsky Z, Levy O (2015a) Negative response of photosynthesis to natural and projected high seawater temperatures estimated by pulse amplitude modulation fluorometry in a temperate coral. Front Physiol 6:317

Caroselli E, Nanni V, Levy O, Falini G, Dubinsky Z, Goffredo S (2015b) Latitudinal variations in biometry and population density of a Mediterranean solitary coral suggest higher tolerance to seawater warming for non-zooxanthellate species. Limnol Oceanogr 60:1356-1370

Caroselli E, Zaccanti F, Mattioli G, Falini G, Levy O, Dubinsky Z, Goffredo S (2012) Growth and demography of the solitary scleractinian coral Leptopsammia pruvoti along a sea surface temperature gradient in the Mediterranean Sea. PLoS ONE 7:e37848

Caroselli E, Ricci F, Brambilla V, Mattioli G, Levy O, Falini G, Dubinsky Z, Goffredo S (2016) Relationships between growth, population dynamics, and environmental parameters in the solitary non-zooxanthellate scleractinian coral Caryophyllia inornata along a latitudinal gradient in the Mediterranean Sea. Coral Reefs 35:507-519

Caroselli E, Prada F, Pasquini L, Nonnis Marzano F, Zaccanti F, Falini G, Levy O, Dubinsky Z, Goffredo S (2011) Environmental implications of skeletal micro-density and porosity variation in two scleractinian corals. Zoology 114:255-264 
Carricart-Ganivet JP (2004) Sea surface temperature and the growth of the West Atlantic reef-building coral Montastrea annularis. J Exp Mar Biol Ecol 302:249-260

Chadwick-Furman NE, Goffredo S, Loya Y (2000) Growth and population dynamic model of the reef coral Fungia granulosa Klusinger, 1879 at Eilat, northern Red Sea. J Exp Mar Biol Ecol 249:199-218

Chamberlain JA (1978) Mechanical properties of coral skeleton: compressive strength and its adaptive significance. Paleobiology 4:419-435

Cuif JP, Dauphin Y, Gautret P (1999) Compositional diversity of soluble mineralizing matrices in some recent coral skeletons compared to fine-scale growth structures of fibres: discussion of consequences for biomineralization and diagenesis. Int Journ Earth Sciences 88:582-592

Dodge RE, Brass GW (1984) Skeletal extension, density and calcification of the reef coral Montastrea annularis: St. Croix, US Virgin Islands. Bull Mar Sci 34:288-307

Dustan P (1982) Depth-dependent photoadaptation by zooxanthellae of the reef coral Montasrea annularis. Mar Biol 68:253-264

Edmunds P, Gates R (2002) Normalizing physiological data for scleractinian corals. Coral Reefs 21:193-197

Einbinder S, Mass T, Brokovich E, Dubinsky Z, Erez J, Tchernov D (2009) Changes in morphology and diet of the coral Stylophora pistillata along a depth gradient. Mar Ecol Prog Ser 381:167-174

Elahi R (2008) Effects of aggregation and species identity on the growth and behavior of mushroom corals. Coral Reefs $27: 881-885$

Elahi R, Edmunds P (2007) Determinate growth and the scaling of photosynthetic energy intake in the solitary coral Fungia concinna (Verril). J Exp Mar Biol Ecol 349:183-193

Erftemeijer PLA, Riegl B, Hoeksema BW, Todd PA (2012) Environmental impacts of dredging and other sediment disturbances on corals: A review. Mar Pollut Bull 64:1737-1765

Falini G, Fermani S, Goffredo S (2015) Coral biomineralization: a focus on intra-skeletal organic matrix and calcification. Semin Cell Dev Biol 46:17-26

Fantazzini P, Mengoli S, Evangelisti S, Pasquini L, Mariani M, Brizi L, Goffredo S, Caroselli E, Prada F, Falini G, Levy O, Dubinsky Z (2013) A time-domain nuclear magnetic resonance study of Mediterranean scleractinian corals reveals skeletal-porosity sensitivity to environmental changes. Environ Sci Technol 47:12679-12686

Fantazzini P, Mengoli S, Pasquini L, Bortolotti V, Brizi L, Mariani M, Di Giosia M, Fermani S, Capaccioni B, Caroselli E, Prada F, Zaccanti F, Levy O, Dubinsky Z, Kaandorp JA, Konglerd P, Hammel JU, Dauphin Y, Cuif J-P, Weaver JC, Fabricius KE, Wagermaier W, Fratzl P, Falini G, Goffredo S (2015) Gains and losses of coral skeletal porosity changes with ocean acidification acclimation. Nat Commun 6:7785

Foster AB, Johnson KG, Schultz LL (1988) Allometric shape change and heterocrony in the free-living coral Trachyphyllia bilobata (Duncan). Coral Reefs 7:37-44

Gerrodette T (1979) Ecological studies of two temperate solitary corals. Ph.D. thesis, University of California, p 112

Gittenberger A, Reijnen BT, Hoeksema BW (2011) A molecularly based phylogeny reconstruction of mushroom corals (Scleractinia: Fungiidae) with taxonomic consequences and evolutionary implications for life history traits. Contrib Zool 80:107-132

Goffredo S, Chadwick-Furman NE (2003) Comparative demography of mushroom corals (Scleractinia, Fungiidae) at Eilat, northern Red Sea. Mar Biol 142:411-418

Goffredo S, Arnone S, Zaccanti F (2002) Sexual reproduction in the Mediterranean solitary coral Balanophyllia europaea (Scleractionia, Dendrophylliidae). Mar Ecol Prog Ser 229:83-94
Goffredo S, Mattioli G, Zaccanti F (2004) Growth and population dynamics model of the Mediterranean solitary coral Balanophyllia europaea (Scleractinia, Dendrophylliidae). Coral Reefs 23:433-443

Goffredo S, Caroselli E, Mattioli G, Zaccanti F (2010) Growth and population dynamic model for the non-zooxanthellate temperate solitary coral Leptopsammia pruvoti (Scleractinia, Dendrophylliidae). Mar Biol 157:2603-2612

Goffredo S, Caroselli E, Pignotti E, Mattioli G, Zaccanti F (2007) Variation in biometry and population density of solitary corals with environmental factors in the Mediterranean Sea. Mar Biol 152:351-361

Goffredo S, Caroselli E, Mattioli G, Pignotti E, Zaccanti F (2008) Relationships between growth, population structure and sea surface temperature in the temperate solitary coral Balanophyllia europaea (Scleractinia, Dendrophylliidae). Coral Reefs 27:623-632

Goffredo S, Caroselli E, Mattioli G, Pignotti E, Dubinsky Z, Zaccanti $F$ (2009) Inferred level of calcification decreases along an increasing temperature gradient in a Mediterranean endemic coral. Limnol Oceanogr 54:930-937

Goffredo S, Mancuso A, Caroselli E, Prada F, Dubinsky Z, Falini G, Levy O, Fantazzini P, Pasquini L (2015) Skeletal mechanical properties of Mediterranean corals along a wide latitudinal gradient. Coral Reefs 34:121-132

Goffredo S, Caroselli E, Mezzo F, Laiolo L, Vergni P, Pasquini L, Levy O, Zaccanti F, Tribollet A, Dubinsky Z, Falini G (2012) The puzzling presence of calcite in skeletons of modern solitary corals from the Mediterranean Sea. Geochim Cosmochim Acta 85:187-199

Gökaşan E, Ergin M, Özyalvaç M, Sur Hİ, Tur H, Görüm T, Ustaömer T, Batuk FG, Alp H, Birkan H, Türker A, Gezgin E, Özturan M (2008) Factors controlling the morphological evolution of the Çanakkale Strait (Dardanelles, Turkey). Geo-Mar Lett 28:107-129

Grigg RW (1982) Darwin point: a threshold for atoll formation. Coral Reefs 1:29-34

Grigg RW, Maragos JE (1974) Recolonization of hermatypic corals on submerged lava flows in Hawaii. Ecology 55:387-395

Hamel JF, Sun Z, Mecier A (2010) Influence of size and seasonal factors on the growth of deep-sea coral Flabellum alabastrum in mesocosm. Coral Reefs 29:521-525

Helmle KP, Dodge RE, Ketcham RA (2000) Skeletal architecture and density banding in Diploria strigosa by X-ray computed tomography. Proc 9th Int Coral Reef Symp 1:365-371

Hoeksema BW (1991) Evolution of body size in mushroom corals (Scleractinia, Fungiidae) and its ecomorphological consequences. Neth J Zool 41:112-129

Hoeksema BW, Waheed Z (2011) Initial phase of autotomy in fragmenting Cycloseris corals at Semporna, eastern Sabah, Malaysia. Coral Reefs 30:1087

Huang D, Benzoni F, Fukami H, Knowlton N, Smith ND, Budd AF (2014) Taxonomic classification of the reef coral families Merulinidae, Montastraeidae and Diploastraeidae (Cnidaria: Anthozoa: Scleractinia). Zool J Linn Soc 171:277-355

Hughes TP, Jackson JBC (1985) Population dynamics and life histories of foliaceous corals. Ecol Monogr 55:141-166

Huston M (1985) Variation in coral growth rates with depth at Discovery Bay, Jamaica. Coral Reefs 4:19-25

Iluz D, Dubinsky Z (2015) Coral photobiology: new light on old views. Zoology 118:71-78

Johnson KG (1992) Population dynamics of a free-living coral: recruitment, growth and survivorship of Manicina areolata (Linnaeus) on the Caribbean coast of Panama. J Exp Mar Biol Ecol 225:253-267 
Jokiel PL, Coles SL (1990) Response of Hawaiian and other IndoPacific reef corals to elevated temperatures. Coral Reefs $8: 155-162$

Kleypas JA, Danabasoglu G, Lough JM (2008) Potential role of the ocean thermostat in determining regional differences in coral reef bleaching events. Geophys Res Lett 35:L03613

Knittweis L, Jompa J, Richter C, Wolff M (2009) Population dynamics of the mushroom coral Heliofungia actiniformis in the Spermonde Archipelago, South Sulawesi, Indonesia. Coral Reefs 28:793-804

Knuston DW, Buddemeier RW, Smith SV (1972) Coral chronometers: seasonal growth bands in reef corals. Science 177:270-272

Krief S, Hendy EJ, Fine M, Yam R, Meibom A, Foster GL, Shemesh A (2010) Physiological and isotopic response of scleractinian corals to ocean acidification. Geochim Cosmochim Acta 74:4988-5001

Kružić P, Sršen P, Benković L (2012) The impact of seawater temperature on coral growth parameters of the colonial coral Cladocora caespitosa (Anthozoa, Scleractinia) in the eastern Adratic Sea. Facies 58:477-491

Liddle MJ, Kay AM (1987) Resistance, survival and recovery of trampled corals on the Great Barrier Reef. Biol Conserv 42:1-18

Logan A, Anderson IH (1991) Skeletal extension growth rate assessment in corals, using CT scan imagery. Bull Mar Sci 49:847-850

Lough JM, Barnes DJ (2000) Environmental controls on growth of the massive coral Porites. J Exp Mar Biol Ecol 245:225-243

Maor-Landaw K, Ben-Asher HW, Karako-Lampert S, Salmon-Divon M, Prada F, Caroselli E, Goffredo S, Falini G, Dubinsky Z, Levy O (2017) Mediterranean versus Red sea corals facing climate change, a transcriptome analysis. Sci Rep 7:42405

Marhsall P (2000) Skeletal damage in reef corals: relating resistance to colony morphology. Mar Ecol Prog Ser 200:177-189

Özalp HB, Alparslan M (2011) In situ studies on scleractinian corals around Çanakkale Strait (Marmara Sea). Proceedings of the 5th International Underwater Research Symposium, pp 4-9

Özalp HB, Alparslan M (2016) Scleractinian diversity in the Dardanelles and Marmara Sea (Turkey): morphology, ecology and distributional patterns. Oceanol Hydrobiol Stud 45:259-285

Özalp HB, Sengun F, Karaca Z, Hisar O (2014) A preliminary study on habitat characteristics and substrate preference of coral species distributed in the Dardanelles. Mar Sci Techn Bull 3:5-10

Pamukcu P, Serengil Y, Yurtseven I (2014) Role of forest cover, land use change and climate change on water resources in Marmara basin of Turkey. iForest 8:480-486
Peirano A, Morri C, Bianchi CN (1999) Skeleton growth and density pattern of the temperate, zooxanthellate scleractinian Cladocora caespitosa from the Liguarian Sea (NW Mediterranean). Mar Ecol Prog Ser 185:195-201

Potvin C, Roff DA (1993) Distribution-free and robust statistical methods: viable alternatives to parametric statistic? Ecology 74:1617-1628

Pratchett MS, Anderson KD, Hoogenboom MO, Widman E, Baird AH, Pandolfi JM, Edmunds PJ, Lough JM (2015) Spatial, temporal and taxonomic variation in coral growth-implications for the structure and function of coral reef ecosystems. Oceanogr Mar Biol 53:215-295

Reynaud S, Leclercq N, Romaine-Lioud S, Ferrier-Pagès C, Jaubert J, Gattuso JP (2003) Interacting effects of $\mathrm{CO}_{2}$ partial pressure and temperature on photosynthesis and calcification in a scleractinian coral. Glob Chang Biol 9:1660-1668

Rodgers K, Cox E, Newston C (2003) Effects of mechanical fracturing and experimental trampling on Hawaiian corals. Environ Manage 31:377-384

Rosenfeld M, Bresler V, Abelson A (1999) Sediment as a possible source of food for corals. Ecol Lett 2:345-348

Sakai K (1998) Effect of colony size, polyp size, and budding mode of egg production in a colonial coral. Biol Bull 195:319-325

Smith SV, Harrison JT (1977) Calcium carbonate production of the mare incognitum, the upper windward reef slope, at Enewetak Atoll. Science 197:556-559

Sparre P, Venema SC (1998) Introduction to tropical fish stock assessment: part 1, manual. FAO Fisheries technical paper 306, Rev 2, FAO, Rome

Stafford-Smith MG, Ormond RFG (1992) Sediment-rejection mechanism of 42 species of Australian Scleractinian. Aust J Mar Fresh Res 43:683-705

Todd PA (2008) Morphological plasticity in scleractinian corals. Biol Rev 83:315-337

von Bertalanffy L (1938) A quantitative theory of organic growth (inquiries on growth laws II). Hum Biol 10:181-213

Vongsavat V, Winotai P, Meejoo S (2006) Phase transitions of natural corals monitored by ESR spectroscopy. Nucl Instrum Methods Phys Res B 243:167-173

Yamashiro H, Nishihira M (1998) Experimental study of growth and asexual reproduction in Diaseris distorta (Michelin, 1843), a free-living fungoid coral. J Exp Mar Biol Ecol 225:253-267

Zibrowius H (1980) Les scléractiniaires de la Méditerraée et de l' Atlantique nord-oriental. Mém Inst Océanogr Monaco 11:1-284 